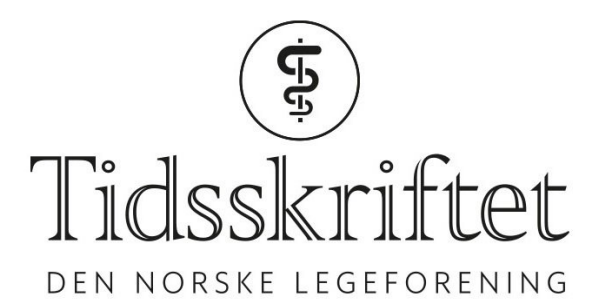

\title{
Presentasjon av tall: Ikke la deg lure
}

KOMMENTAR

MAGNUS LØBERG

E-post: magnus.loberg@medisin.uio.no

Magnus Løberg er førsteamanuensis ved Universitetet i Oslo.

\section{MICHAEL BRETTHAUER}

Ingen av forfatterne har oppgitt noen interessekonflikter.

Sondén og medarbeidere sammenligner kvinner med og uten brystimplantat som deltok i mammografiprogrammet (1). Kvinner med brystimplantat hadde lavere risiko for brystkreft, men hadde mer avansert sykdom på diagnosetidspunktet. Fremstillingen gir inntrykk av at brystimplantat er en risikofaktor for alvorlig brystkreft $(1,2)$. Men dataene som presenteres støtter ikke dette.

Forfatterne presenterer forekomst av avansert brystkreft som andel av alle kvinner diagnostisert med brystkreft. Dette gir et feilaktig bilde fordi testhyppighet (mammografi) påvirker antall brystkreftdiagnoser og dermed andelen (3). Den korrekte fremstillingen av resultatene er å bruke rater av avansert sykdom blant kvinner med og uten implantat, da disse ikke påvirkes av testhyppighet.

Raten av lymfeknutepositiv sykdom fra Sondén og medarbeidere er 104 og 92 per 100 ooo person-år for kvinner henholdsvis med og uten implantat; en ikke-statistisk signifikant forskjell på 12 per 100 ooo person-år. Tilsvarende er raten av svulster med diameter over 20 millimeter 114 og 98 per 100 ooo person-år for kvinner henholdsvis med og uten implantat; en ikke-statistisk signifikant forskjell på 16 per 100 ooo person-år. Informasjon om lymfeknutestatus og svulststørrelse manglet hos noen kvinner, men å ekskludere disse fra analysene endret ikke resultatene.

Den riktige konklusjonen er dermed at kvinner med og uten brystimplantat har lik risiko for avansert brystkreft. Denne endringen i konklusjon kan synes liten, men er viktig for kvinner som vurderer brystimplantat og for hvilke anbefalinger kvinnene skal få.

Hvordan vi presenterer resultater har blitt aktualisert den siste tiden: Våren 2020 opplever vi en situasjon der sammenblanding av mål på risiko bidrar til forvirring og frykt blant beslutningstagere og i befolkningen. Vi har fătt høre skremmende anslag over letalitetsrater, andelen som dør av sykdommen blant alle som er diagnostisert med COVID-19 infeksjon. Dette har feilaktig blitt presentert og tolket som risiko for å dø blant de smittede og brukt for å sammenligne land med ulik teststrategi (4). Men letalitetsrate kan ikke brukes for å si hvor farlig det er å bli smittet. Da må vi vite om alle som er smittet (eller i et tverrsnitt av befolkningen), både med og uten symptomer. Først da kan vi beregne hvilken andel av de smittede som dør, og gjøre veloverveide valg for enkeltindivid, 
helsevesen og samfunn.

Risikokommunikasjon er krevende, men livsviktig - enten det er snakk om individets valg om egen helse eller samfunnets respons på en pandemi. Dette stiller særlige krav til vår formidlingsevne. Vi må ikke la oss lure av tallene.

\section{LITTERATUR:}

1. Sondén ECB, Sebuødegård S, Korvald C et al. Kosmetiske brystimplantater og brystkreft. Tidsskr Nor Legeforen 2020;140. doi: 10.4045/tidsskr.19.0266. [PubMed][CrossRef]

2. Skaane P. Brystimplantater til besvær. Tidsskr Nor Legeforen 2020; 140. doi: 10.4045/tidsskr.20.0015. [PubMed][CrossRef]

3. Kalager M, Adami HO, Bretthauer M et al. Overdiagnosis of invasive breast cancer due to mammography screening: results from the Norwegian screening program. Ann Intern Med 2012; 156: 491-9. [PubMed][CrossRef]

4. Rajgor DD, Lee MH, Archuleta S et al. The many estimates of the COVID-19 case fatality rate. Lancet Infect Dis 2020; Mar 27: S1473-3099(20)30244-9. [PubMed][CrossRef]

Publisert: 25. mai 2020. Tidsskr Nor Legeforen. DOI:10.4045/tidsskr.20.0378

(C) Tidsskrift for Den norske legeforening 2020. Lastet ned fra tidsskriftet.no 